\title{
Wykorzystanie przenośnego spektrometru FT-IR do określania pótilościowego składu mineralogicznego skał zbiornikowych
}

\begin{abstract}
Analiza półilościowa składu mineralogicznego skał przy pomocy przenośnego spektrometru FT-IR jest metodą szybką i może stanowić ciekawą alternatywę dla innych metod analitycznych, takich jak XRD i XRF. Modele stworzone za pomocą algorytmu Beera będące podstawą do opracowania metodyki do analizy półilościowej dają bardzo dobre rezultaty, charakteryzując się wysokim współczynnikiem determinacji $R^{2}$ dla widm podczerwonych oraz metod XRD i XRF. Przenośny spektrometr FT-IR może być z powodzeniem użyty zarówno w pomiarach laboratoryjnych, jak i terenowych. Metoda FT-IR może umożliwić szybką ocenę litologiczną przewiercanych warstw oraz jest pomocna przy wyborze prób do dalszych badań laboratoryjnych. W niniejszym artykule przedstawiono wstępne wyniki analizy półilościowej składu mineralogicznego skał zbiornikowych opartej na korelacji widm FT-IR z wynikami analiz XRF i XRD.
\end{abstract}

Słowa kluczowe: FT-IR, XRF, XRD, analiza półilościowa, skład mineralogiczny.

\section{The use of portable FT-IR spectrometer for semi-quantitative analysis of mineralogical composition of reservoir rocks}

\begin{abstract}
Semi-quantitative analysis of mineralogical composition of reservoir rocks with the use of portable FT-IR spectrometer is a quick analytical method and might be an interesting alternative to other methods such as XRD and XRF. Models created using Beer's algorithm being the basis of methodology for semi-quantitative analysis, have given very good results with a high $R^{2}$ determination coefficient, for infrared spectra and methods such as XRD and XRF. Portable FT-IR spectrometer can be successfully used for laboratory analyses as well as field measurements. The opportunity to analyze the mineralogical composition of rocks allows for quick lithological assessment of drilled layers and helps during sampling for further laboratory testing. This article shows preliminary results of semi-quantitative analyses of mineralogical composition of reservoir rocks based on correlations of infrared spectra with XRF and XRD results.
\end{abstract}

Key words: FT-IR, XRF, XRD, semi-quantitative analysis, mineralogical composition.

\section{Wstęp}

Spektroskopia w podczerwieni z transformacją Fouriera jest od lat z powodzeniem wykorzystywana do analizy szerokiego zakresu minerałów budujących skały zbiornikowe [6]. W porównaniu z dyfraktometrią rentgenowską XRD spektroskopia w podczerwieni jest szybka, a przy tym umożliwia pomiar materiałów amorficznych, półkrystalicznych oraz krystalicznych, dostarczając jednocześnie informacji zarówno o ich strukturze, jak i składzie chemicznym. Analiza składu mineralogicznego na podstawie składu chemicznego również wymaga wyszukanych technik analitycznych, które tak jak dyfraktometria rentgenowska są czasochłonne oraz charakteryzują się złożoną metodyką przygotowania próbek do badań. Spektroskopia w podczerwieni stanowi obiecującą alternatywę dla innych technik, gdyż wymaga mniej czasu 
zarówno na przygotowanie materiału do badań, jak i na sam pomiar oraz interpretację wyników [7]. Müller i inni [6] dowiedli, że spektroskopia w zakresie średniej podczerwieni (mid-infrared), tj. o liczbie falowej 400 $\div 4000 \mathrm{~cm}^{-1}$ (długo- ści fali $25 \div 2,5 \mu \mathrm{m}$ ), jest skuteczną techniką do analizy jakościowej oraz ilościowej minerałów skał zbiornikowych ze względu na wibracje wiązań charakterystycznych dla nich grup funkcyjnych znajdujących się w owym zakresie.

\section{Podstawy fizyczne metody i zasada działania spektrometru}

Zastosowanie spektroskopii w podczerwieni do badań skał osadowych opiera się głównie na interpretacji długości fali lub częstotliwości odrębnych maksimów absorpcji, prowadząc do identyfikacji poszczególnych molekuł zawartych w minerałach. Wartości te pochodzą od normalnych wibracji różnych wiązań chemicznych lub grup atomów (grup funkcyjnych) tworzących wiązania kowalencyjne, takich jak aniony kompleksowe $\left(\mathrm{OH}^{-}, \mathrm{CO}_{3}{ }^{2-}, \mathrm{C}_{2} \mathrm{O}_{4}{ }^{2-}, \mathrm{SO}_{4}{ }^{2-}, \mathrm{PO}_{4}{ }^{3-}, \mathrm{SiO}_{4}{ }^{4-}\right.$, $\left.\mathrm{Si}_{2} \mathrm{O}_{7}{ }^{6-}\right)$, kationy poliatomowe $\left(\mathrm{H}_{3} \mathrm{O}^{+}, \mathrm{NH}^{4+}, \mathrm{UO}_{2}{ }^{2+}\right.$ itd. $)$, molekuły obojętne $\left(\mathrm{H}_{2} \mathrm{O}, \mathrm{NH}_{3}, \mathrm{CO}_{2}\right)$, jak również od wibracji warstw oraz struktur będących częścią sieci krystalicznych minerałów. Inny rodzaj identyfikacji, również wykorzystujący odrębne maksima pasm, opiera się na korelacji między częstotliwościami wibracji a cechami poszczególnych minerałów (siła wiązań wodorowych, stopień podstawień izomorficznych itd.). Zakresy częstotliwości charakterystycznych wibracji najważniejszych grup poliatomowych oraz jonów kompleksowych opisali Miller i Wilkins [4] oraz Povarennykh [8].

Zasada działania spektrometru w podczerwieni z transformacją Fouriera [11] opiera się na zjawisku interferencji zachodzącej między dwiema wiązkami promieniowania, co w efekcie daje interferogram. Jest to sygnał powstający w wyniku różnicy drogi optycznej dwóch wiązek. Odległość oraz częstotliwość są domenami, które mogą przechodzić w siebie nawzajem dzięki metodzie matematycznej znanej jako transformacja Fouriera.

Promieniowanie podczerwone pochodzące ze źródła jest przepuszczane przez interferometr, a następnie wchodzi w interakcję z próbką, by ostatecznie dotrzeć do detektora. Po wzmocnieniu sygnału, w trakcie którego dochodzi do wyeliminowania przez filtr wpływu wysokiej częstotliwości, dane są konwertowane do formy cyfrowej oraz przesłane dalej do komputera w celu dokonania transformacji Fouriera.

Najczęściej stosowanym interferometrem w spektroskopii FT-IR jest interferometr Michelsona, który składa się $\mathrm{z}$ dwóch prostopadle ustawionych względem siebie zwierciadeł; dzielnik wiązki, będący półprzepuszczalnym filmem, przecina płaszczyzny obydwu zwierciadeł, jak to zostało pokazane na rysunku 1. Materiał, z którego wykonany jest dzielnik wiązki, musi być dobrany w zależności od rejonu badanego widma. W przypadku spektrometru Cary 630 dzielnik wiązki wykonany został z selenu cynku ZnSe o zakresie liczby falowej $600 \div 4000 \mathrm{~cm}^{-1}(25 \div 2,5 \mu \mathrm{m})$.

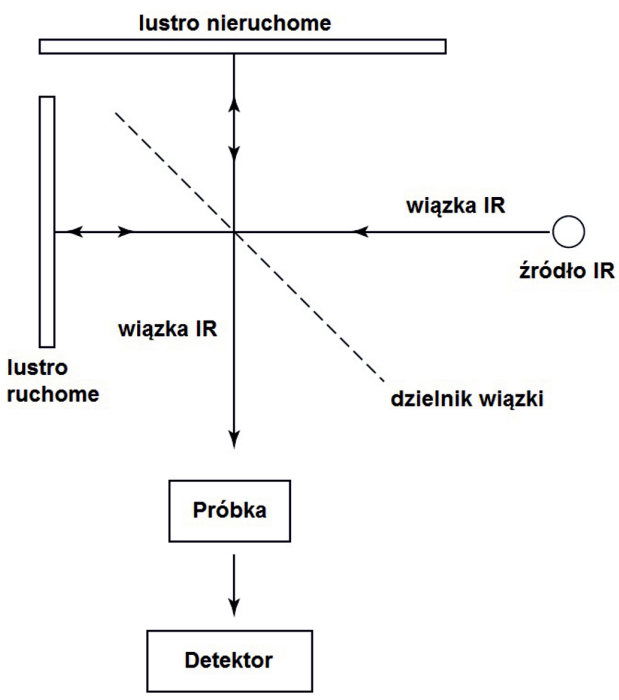

Rys. 1. Budowa interferometru Michelsona (zmodyfikowany) [11]

Jeśli skolimowana wiązka promieniowania monochromatycznego o określonej długości fali $\lambda(\mathrm{cm})$ przechodzi przez dzielnik wiązki, z założenia doskonały, to $50 \%$ tego promieniowania zostanie odbite i padnie na jedno zwierciadło, natomiast drugie $50 \%$ wiązki zostanie przepuszczone przez dzielnik i padnie na drugie zwierciadło. Obie wiązki zostaną odbite od zwierciadeł i powrócą do dzielnika. W efekcie nałożą się na siebie i ulegną interferencji. 50\% wiązki odbitej od zwierciadeł zostaje przepuszczone przez dzielnik i powraca do źródła, natomiast drugie $50 \%$ wchodzi w interakcję z próbką. Lustro ruchome powoduje różnice drogi optycznej między dwoma ramionami interferometru [11].

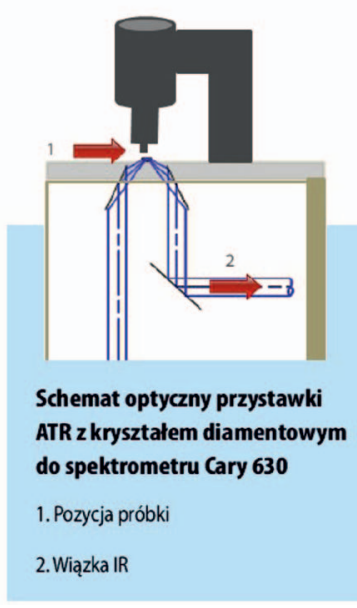

Rys. 2. Schemat optyczny przystawki ATR (zmodyfikowany) [1] 
Do wykonania pomiarów użyto spektrometru z przystawką ATR (attenuated total reflectance), (rysunek 2) wykorzystującą zjawisko całkowitego osłabionego wewnętrznego odbicia (total internal reflection). Wiązka promieniowania wpadająca do kryształu, w tym przypadku diamentowego, podlega całkowitemu wewnętrznemu odbiciu, jeżeli kąt padania tej wiązki na powierzchnię znajdującą się między próbką a kryształem jest większy do kąta krytycznego, będącego funkcją współczynników załamania dla obu powierzchni. Wiązka, wychodząc częściowo poza powierzchnię kryształu, odbija się od powierzchni badanego materiału, który jest w kontakcie z kryształem (rysunek 3). Powoduje to, że odbita wiązka ulega osłabieniu w wyniku absorpcji energii charakterystycznej dla danej długości fali, a następnie zostaje zarejestrowana przez detektor. Wynikiem absorpcji jest widmo z pasmami odpowiadającymi składowi molekularnemu próbki (rysunek 4), które może zostać przedstawione jak absorbancja lub transmitancja w procentach.

Głębokość penetracji $\left(d_{p}\right)$ promieniowania w spektroskopii ATR jest funkcją długości fali $\lambda$, współczynników załamania promieniowania dla ośrodków $n_{1}$ i $n_{2}$ oraz kąta padania promieniowania $\theta$.

$d_{p}$ (depth of penetration), czyli głębokość penetracji dla medium o zerowej absorpcji, wygląda następująco:

$$
d_{p}=\left(\lambda / n_{1}\right) /\left\{2 \pi\left[\sin \theta-\left(n_{1} / n_{2}\right)^{2}\right]^{1 / 2}\right\}
$$

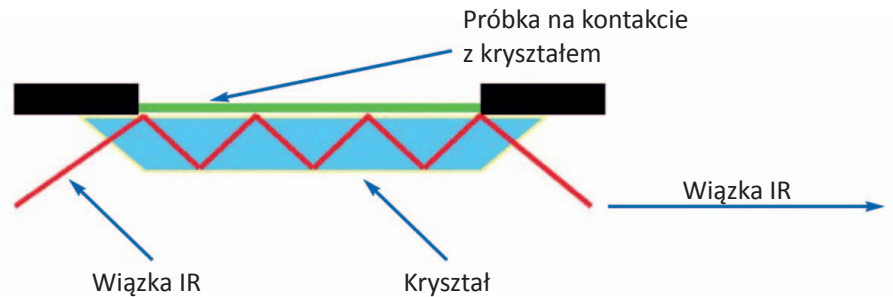

Rys. 3. Schemat optyczny kryształu przystawki ATR (zmodyfikowany) [11]

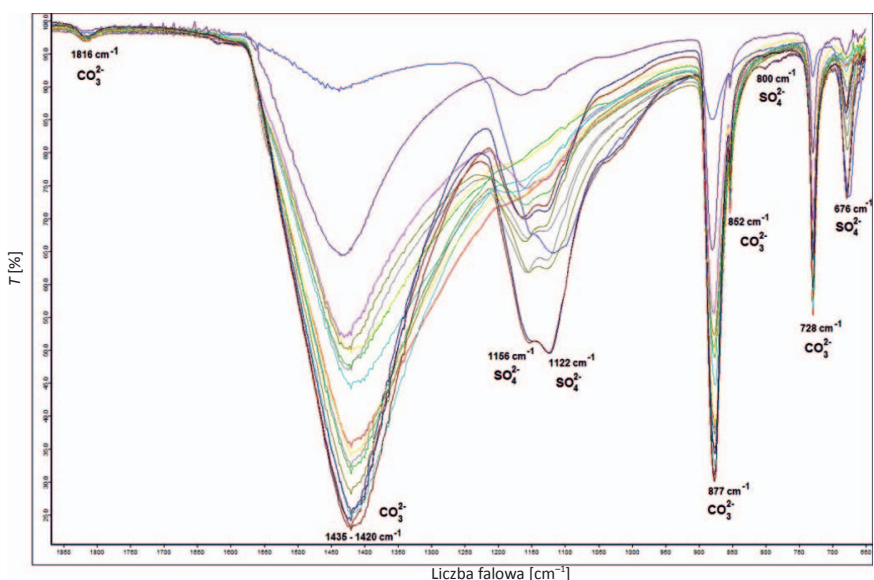

Rys. 4. Przykładowe widma spektrometryczne FT-IR z zaznaczonymi pasmami od drgań wiązań grup funkcyjnych $\mathrm{CO}_{3}{ }^{2-}, \mathrm{SO}_{4}^{2-}(\mathrm{T} \%$ - transmitancja). Źródło: autor

\section{Metodyka badań}

Do badań wybrano 86 próbek skał zbiornikowych o zróżnicowanym składzie mineralogicznym pochodzących z 7 otworów wiertniczych z różnych rejonów geologicznych Polski. Próbki skał z otworów wiertniczych, po wcześniejszym skruszeniu, zmielono na młynku planetarnym do frakcji poniżej $20 \mu \mathrm{m}$, a następnie odważono $0,02 \mathrm{~g}$ i zmierzono widma próbek, używając do tego przenośnego spektrometru FT-IR Cary 630 o masie $2,9 \mathrm{~kg}$ z detektorem DTGS, dzielnikiem wiązki ZnSe oraz przystawką ATR (attenuated total reflectance) z kryształem diamentowym. Pomiary dla każdej próbki wykonano przy takich samych ustawieniach pomiaru, tj. 128 skanów przy rozdzielczości $2 \mathrm{~cm}^{-1}$. Czas trwania pomiaru wynosił 2 minuty.

Dokładny skład chemiczny oraz mineralogiczny badanych próbek uzyskano metodami XRF oraz XRD. Pomiar składu chemicznego wykonano za pomocą przenośnego spektrometru S1 TITAN firmy Bruker, wykorzystującego metodę rentgenowskiej analizy fluorescencyjnej z dyspersją energii (EDXRF). S1 TITAN wyposażony jest w anodę Rh (o parametrach maksymalnie: $50 \mathrm{kV}, 100 \mu \mathrm{A}, 4 \mathrm{~W}$ ) i detektor $10 \mathrm{~mm}^{2}$ X-Flash ${ }^{\circledR}$ Silicon Drift Detector (SDD) (o typowej rozdzielczości $147 \mathrm{eV}$ dla linii Mn K-alfa). Analiza składu chemicznego odbywa się z wykorzystaniem me- tody parametrów fundamentalnych, pozwalającej na wykonywanie pomiarów bez konieczności stosowania wzorców. Spektrometr umożliwia analizę zawartości pierwiastków z zakresu od Mg do U [10]. Podstawową zaletą metody jest to, że wyniki uzyskuje się natychmiast po przeprowadzeniu pomiaru. Wyniki mogą być podawane w formie tlenkowej lub pierwiastkowej i należy zaznaczyć, że nie są normalizowane do $100 \%$.

Ilościowy skład mineralogiczny badanych próbek został wyliczony metodą Rietvelda za pomocą programu komputerowego SIROQUANT, o udokumentowanej przydatności do analizy składu skał zawierających również minerały ilaste [2]. Metoda stosowana jest w coraz większej liczbie programów do analizy składu mineralnego przy użyciu dyfrakcji rentgenowskiej [9]. Daje ona możliwość komputerowego modelowania struktury krystalograficznej konkretnych minerałów występujących w badanym materiale, a następnie wykorzystywania ich jako wzorców przy analizie składu ilościowego. Podczas modelowania struktury atomowej poszczególnych minerałów możliwe jest uwzględnienie ich rzeczywistego składu chemicznego, rozmiarów krystalitów, obecności defektów strukturalnych czy stopnia dezorientacji preparatu. Pomiary ilościowe wykonane 
zostały na aparacie X'Pert Pro firmy Panalytical, wyposażonym w nowoczesny licznik paskowy X'Celerator. Zastosowano napięcie wzbudzenia $40 \mathrm{kV}$, natężenie prądu anodowego $34 \mathrm{~mA}$, krok pomiarowy $0,02^{\circ} 2 \theta$ oraz zakres pomiarowy od 5 do $65^{\circ} 2 \theta$. Preparaty pomiarowe dezorientowane sporządzane są zgodnie z procedurą zalecaną specjalnie do skał zawierających dużą ilość minerałów ilastych [12]. W rentgenowskiej analizie ilościowej właściwa preparatyka jest nieodzowna dla uzyskania poprawnych wyników. Próbka musi być zmielona do odpowiedniej wielkości ziaren (poniżej $20 \mu \mathrm{m}$ ) i homogeniczna (równomiernie wymieszana z wzorcem wewnętrznym). Aby sprostać tym wymaganiom, do 2,7 g wstępnie zmielonej próbki dodawano $0,3 \mathrm{~g} \mathrm{ZnO}$ (10\%) i całość mielono na mokro (z metanolem) przez 5 minut w mikromłynku firmy McCrone. Pomiary przeprowadzono na preparatach dezorientowanych ładowanych z boku, co zapewnia uzyskanie rzeczywistych proporcji składników mineralnych występujących w próbkach (unika się błędów związanych z orientacją kryszta- łów o pokroju blaszkowym). Preparat powinien mieć również odpowiednią (około $0,6 \mathrm{~g} / \mathrm{cm}^{3}$ ) i powtarzalną gęstość oraz grubość, aby warunki pomiarowe w przypadku każdej próbki były takie same.

Do stworzenia modeli półilościowych wykorzystano program MicroLab Quant, który wraz z urządzeniem Cary 630 został udostępniony do testów przez firmę MS Spektrum. Modele powstały z zastosowaniem algorytmu Beera. Prawo Beera zakłada [7], że intensywność absorbcji promieniowania przez próbkę jest ściśle związana z ilością składnika lub składników, które to promieniowanie absorbują:

$$
A=\varepsilon c l
$$

gdzie:

$A$ - absorbancja próbki,

$c$ - koncentracja składnika,

$l$-odległość, jaką pokonuje promieniowanie w próbce,

$\varepsilon$ - stała proporcjonalności określana jako absorpcyjność molarna.

\section{Wyniki badań}

\section{Model weglanowy i $\mathrm{CaO}$}

Do stworzenia modelu węglanowego i $\mathrm{CaO}$ wybrano 60 widm wzorcowych pobranych ze skał o różnej zawartości węglanów, takich jak kalcyt (C), dolomit (D) i ankeryt $(\mathrm{An})$, oraz z tlenku wapnia $\mathrm{CaO}$. Za pasmo najbardziej charakterystyczne dla modelu przyjęto pasmo kalcytu, oscylujące w obrębie wartości powyżej $1400 \mathrm{~cm}^{-1}$ [6], pochodzące od drgań asymetrycznych rozciągających grupy $\left(\mathrm{CO}_{3}\right)^{2-}$. Następnie dla wybranego pasma rozpoczęto modelowanie zależności między składem mineralogicznym, chemicznym oraz geometrią pasma $1400 \mathrm{~cm}^{-1}$ na podstawie jego wysokości oraz pola powierzchni. Modelowanie wykonywano manualnie do momentu, aż otrzymano najlepszą korelację $\left(R^{2}\right)$ danego składnika z wybranym pasmem. Jednostki dla wysokości oraz pola danego pasma zostały z góry narzucone przez program i potraktowane jako jednostki umowne ( $W$-wysokość, $P$ - pole) (rysunki 8,9$)$. Zależność zawartości węglanów od tlenku wapnia jest wyraźnie widoczna. Współczynnik korelacji $R^{2}$ wynosi ponad 0,9 (rysunek 5). W uzyskanych modelach współczynniki korelacji również posiadają wysokie wartości. Zależność wysokości pasm oscylujących wokół wartości $1400 \mathrm{~cm}^{-1}$ od zawartości węglanów $(\mathrm{C}+\mathrm{D}+\mathrm{An})$ wynosi $R^{2}=0,97$, a współczynnik korelacji pola powierzchni tych pasm oraz zawartości węglanów $(\mathrm{C}+\mathrm{D}+\mathrm{An})$ jest równy 0,86 (rysunek 8). Współczynniki korelacji wysokości tych pasm oraz ich powierzchni z tlenkiem wapnia $\mathrm{CaO}$ wynoszą kolejno $R^{2}=0,95$ i $R^{2}=0,94$ (rysunek 9).

\section{Model kwarcowy $\boldsymbol{i} \mathrm{SiO}_{2}$}

Do modelu kwarcowego i $\mathrm{SiO}_{2}$ wybrano 48 widm wzorcowych pobranych ze skał o różnej zawartości kwarcu oraz $\mathrm{SiO}_{2}$. Za pasma najbardziej charakterystyczne dla modelu przyjęto pasma oscylujące $\mathrm{w}$ obrębie wartości $1080 \mathrm{~cm}^{-1}$ [6], pochodzące od drgań rozciągających wiązań $\mathrm{Si}-\mathrm{O}$. Następnie, podobnie jak w przypadku modelu węglanowego i $\mathrm{CaO}$, dla wybranych pasm rozpoczęto modelowanie zależności między składem mineralogicznym, chemicznym oraz geometrią pasm na podstawie ich wysokości oraz pola powierzchni. Modelowanie wykonywano manualnie do momentu, aż otrzymano najlepszą korelację $\left(R^{2}\right)$ danego składnika z wybranymi pasmami. Korelacja zawartości kwarcu z zawartością $\mathrm{SiO}_{2}$ plasuje się na poziomie $R^{2}=0,86$ (rysunek 6). Pozostałe współczynniki korelacji dla modelu również są wysokie, tj. $R^{2}$ dla zależności wysokości pasma oraz jego powierzchni od zawartości kwarcu wynosi kolejno 0,81 i 0,78. Natomiast współczynnik korelacji $R^{2}$ dla zależności wysokości pasma oraz jego powierzchni od zawartości $\mathrm{SiO}_{2}$ jest w obu przypadkach równy 0,81 .

\section{Model kaolinitowy i $\mathrm{Al}_{2} \mathrm{O}_{3}$}

Tak jak w przypadku poprzednich modeli - dla modelu kaolinitowego i $\mathrm{Al}_{2} \mathrm{O}_{3}$ wybrano 35 widm wzorcowych pobranych ze skał o różnej zawartości kaolinitu i $\mathrm{Al}_{2} \mathrm{O}_{3}$. W tym dla jednego widma (wzorca kaolinitowego) o najintensywniejszych pasmach charakterystycznych pochodzącego ze skały kaolinitowej założono teoretyczną zawartość 
kaolinitu $100 \%$ oraz zawartość $\mathrm{Al}_{2} \mathrm{O}_{3}$ wynoszącą 39,5\% [5]. Następnie dla pasm charakterystycznych oscylujących w tym przypadku w obrębie $3621 \mathrm{~cm}^{-1}, 3653 \mathrm{~cm}^{-1}, 3697 \mathrm{~cm}^{-1}$ [3] rozpoczęto modelowanie zależności między składem mineralogicznym, chemicznym oraz geometrią pasm. Pasma te pochodzą od drgań rozciągających wiązania $\mathrm{Al}_{2}-\mathrm{OH}$. Korelacja zawartości kaolinitu z zawartością $\mathrm{Al}_{2} \mathrm{O}_{3}$ kształtuje się na poziomie $R^{2}=0,86$ (rysunek 7). Pozostałe współczynniki korelacji dla modelu również są wysokie, tj. $R^{2}$ dla zależności wysokości pasma oraz jego powierzchni od zawartości kaolinitu wynosi kolejno 0,96 i 0,90. Natomiast współczynniki korelacji $R^{2}$ dla zależności wysokości pasma oraz jego powierzchni od zawartości $\mathrm{Al}_{2} \mathrm{O}_{3}$ są kolejno równe 0,92 i 0,91.

Na rysunkach 5-9 zaprezentowano przykładowe korelacje z modelowań.

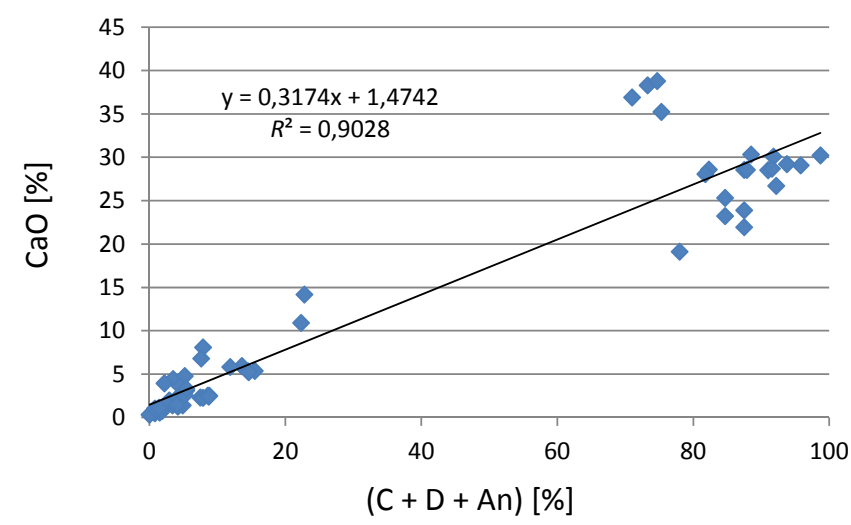

Rys. 5. Zależność między zawartością tlenku wapnia $\mathrm{CaO}$ $\mathrm{z}$ metody XRF oraz sumą minerałów węglanowych $(\mathrm{C}+\mathrm{D}+\mathrm{An}) \mathrm{z}$ metody XRD

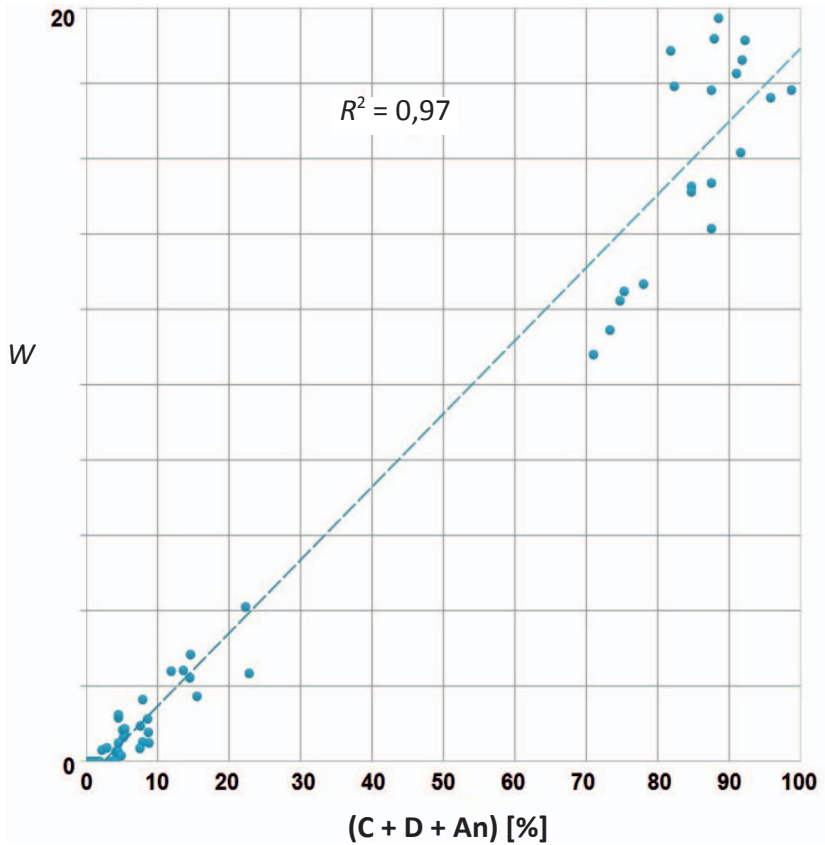

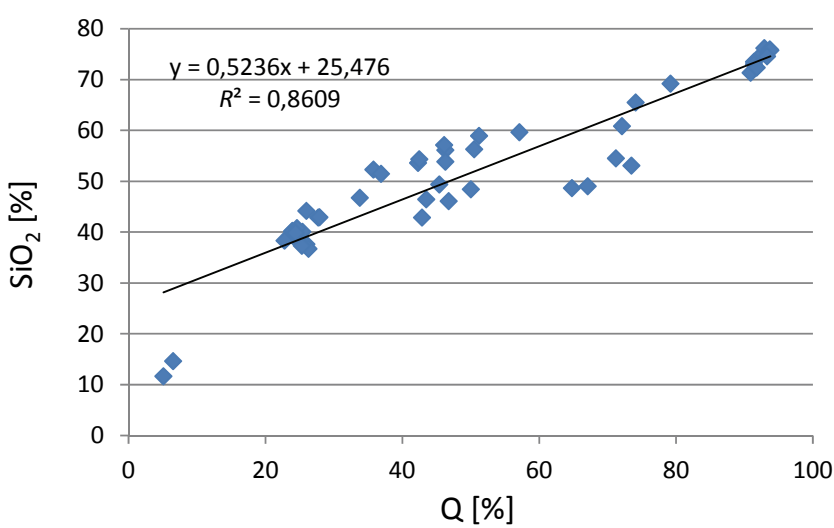

Rys. 6. Zależność między zawartością $\mathrm{SiO}_{2} \mathrm{z}$ metody XRF oraz kwarcem (Q) z metody XRD

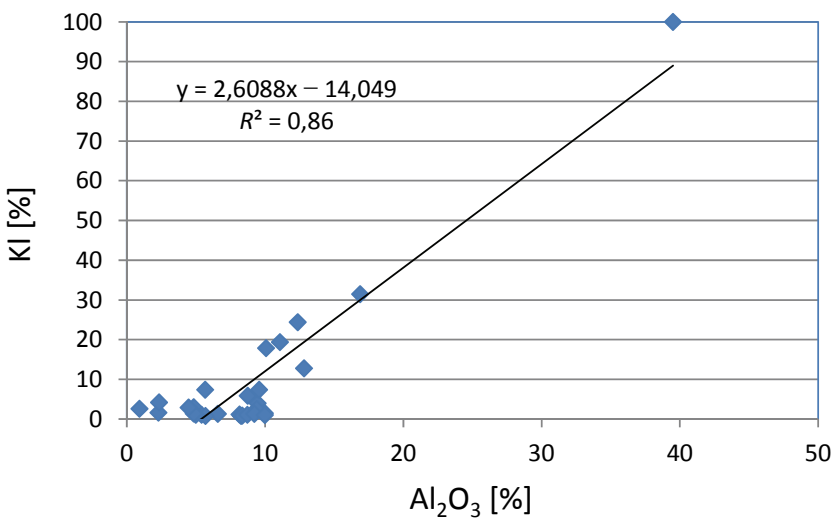

Rys. 7. Zależność między zawartością $\mathrm{Al}_{2} \mathrm{O}_{3}$ z metody XRF oraz kaolinitem $(\mathrm{Kl}) \mathrm{z}$ metody XRD

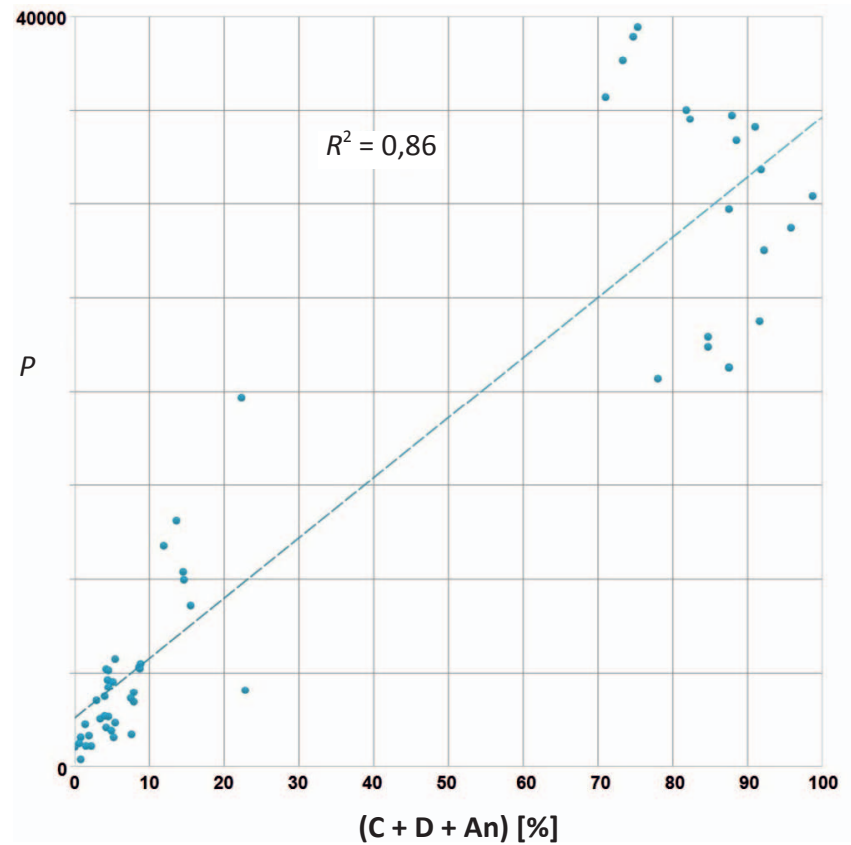

Rys. 8. Zależność między zawartością węglanów a wysokością oraz polem pasma $1400 \mathrm{~cm}^{-1}$ 

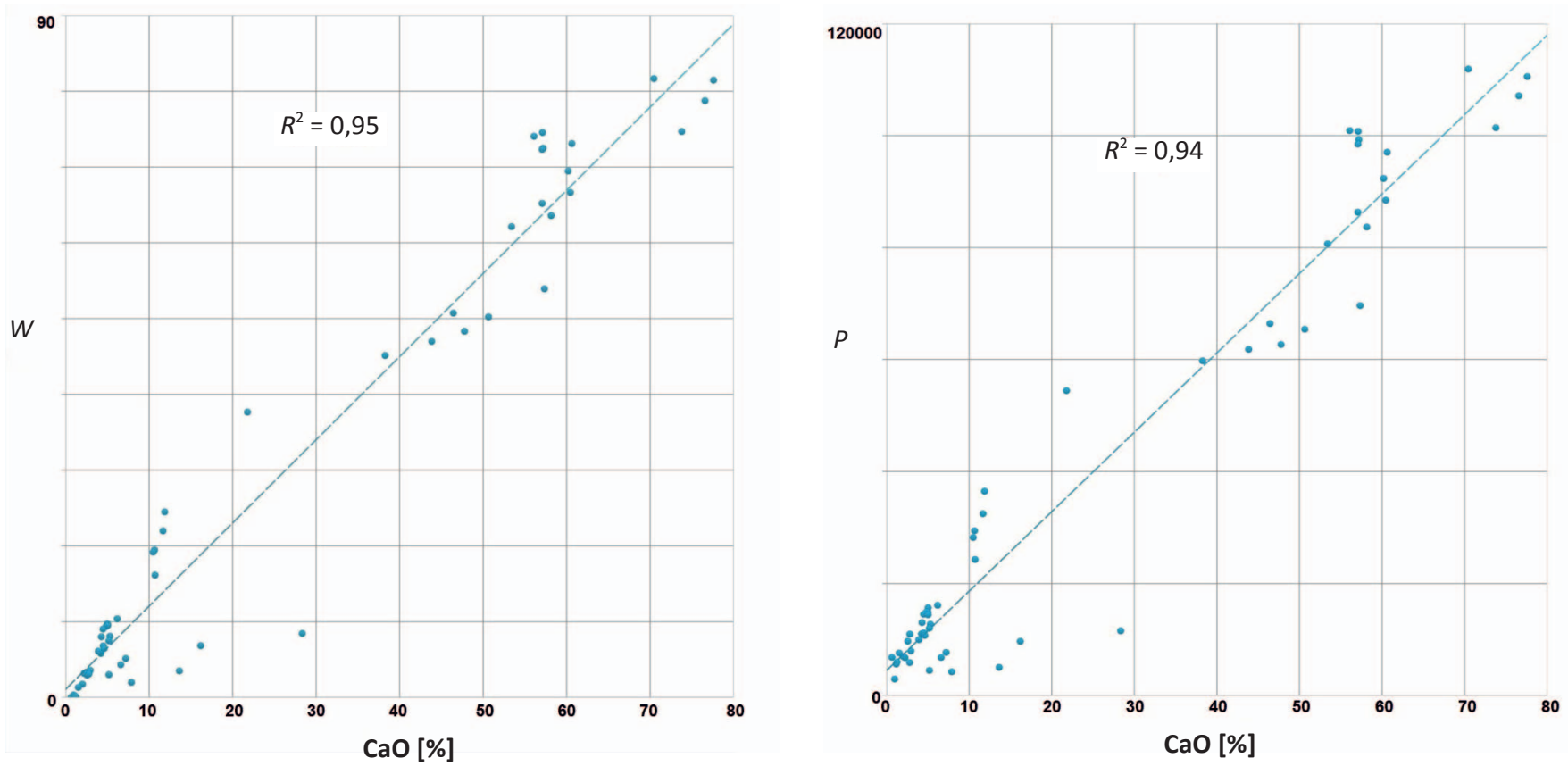

Rys. 9. Zależność między zawartością $\mathrm{CaO}$ a wysokością oraz polem pasma $1400 \mathrm{~cm}^{-1}$

\section{Podsumowanie i wnioski}

1. Spektrometrem Cary 630 przebadano 86 próbek skał zbiornikowych o zróżnicowanym składzie mineralogicznym pochodzących z różnych rejonów geologicznych Polski. Na próbkach wykonano również analizę składu mineralogicznego metodą XRD oraz analizę składu chemicznego metodą XRF.

2. Przygotowanie próbki do pomiaru widma oraz samo wykonanie pomiaru przystawką ATR okazało się bardzo szybkie (pomiar około 2 minut).

3. Jakość otrzymanych widm oraz dostępne oprogramowanie pozwoliły na wykonanie modeli do wstępnej analizy półilościowej wybranych minerałów oraz tlenków wchodzących w ich skład. Uzyskane modele wskazują na wysoki stopień korelacji z wynikami analiz XRD oraz XRF.

4. Należy zwrócić uwagę, że otrzymane korelacje dla modeli półilościowych są wysokie pomimo tego, iż próbki skał reprezentowały różne rejony geologiczne Polski. Oznacza to, że po odpowiednim dopracowaniu metodyki do analizy ilościowej skał spektrometrem FT-IR metoda ta może stać się uniwersalna bez potrzeby tworzenia modeli dla każdego rejonu geologicznego z osobna.

5. Wstępne analizy wykazały, że po odpowiednim dopracowaniu metodyki w przyszłości możliwa będzie szczegółowa analiza ilościowa wybranych minerałów oraz tlenków dająca zadowalające rezultaty, co może stanowić ciekawą alternatywę dla metody XRD oraz XRF.

6. Waga oraz wielkość testowanych spektrometrów pozwalają na komfortowy przewóz urządzenia oraz wykona- nie szybkiego pomiaru próbek/rdzeni wiertniczych bezpośrednio na otworze lub w magazynie rdzeni. Szybki, wstępny pomiar widma może się okazać bardzo pomocny przy typowaniu próbek do dalszych analiz metodą XRD, XRF, a nawet dokładniejszego pomiaru widma stacjonarnym spektrometrem FT-IR.

7. Przenośny spektrometr FT-IR może z powodzeniem zostać użyty w pracach terenowych w trakcie przewiercania warstw geologicznych i posłużyć do pomiaru zwiercin w celu szybkiej oceny litologii.

8. Pomiar metodą FT-IR, mimo że szybki, jest również narażony na wpływ czynników zewnętrznych (np. $\mathrm{H}_{2} \mathrm{O}$ i $\mathrm{CO}_{2} \mathrm{w}$ powietrzu), co z kolei może przekładać się na jakość otrzymywanych widm oraz większy błąd analizy półilościowej.

9. Tworzenie metodyki do określania dokładnego ilościowego składu mineralogicznego skał zbiornikowych jest czasochłonne i wymaga specjalistycznego oprogramowania umożliwiającego wykorzystanie zaawansowanych technik chemometrycznych.

10. Należy pamiętać, że metoda FT-IR pozwala zidentyfikować charakterystyczne grupy funkcyjne (wiązania chemiczne molekuł) budujące minerały, które cechuje zjawisko polaryzacji. Zatem minerały niezawierające takowych nie zostaną wykryte metodą FT-IR.

11. W dalszej perspektywie należy zwrócić uwagę na możliwość stworzenia odpowiedniej metodyki do analizy ilościowej minerałów ilastych czy też identyfikacji 
materii organicznej w skałach źródłowych/zbiornikowych. W przyszłości należy również przyjrzeć się innym przystawkom dostępnym dla testowanych urzą- dzeń, co oprócz badania skał może w istotny sposób poszerzyć ofertę badawczą Zakładu Geofizyki Wiertniczej INiG - PIB.

Prosimy cytować jako: Nafta-Gaz 2017, nr 5, s. 295-301, DOI: 10.18668/NG.2017.05.01

Artykuł nadesłano do Redakcji 29.11.2016 r. Zatwierdzono do druku 7.03.2017 r.

Artykuł powstał na podstawie pracy statutowej pt. Ocena możliwości zastosowania przenośnego spektrometru IR w badaniach skat - praca INiG - PIB na zlecenie MNiSW; nr zlecenia: 0002/SW/16/01, nr archiwalny: DK-4100-2/16.

\section{Literatura}

[1] Agilent Technologies: Agilent Cary 630 FTIR Spectrometer User's Guide. 2012.

[2] Kowalska S.: Określanie ilościowego składu mineralogicznego skat zawierajacych mineraly ilaste metoda Rietvelda. Nafta-Gaz 2013, nr 12, s. 894-902.

[3] Manecki A., Muszyński M. (red.): Przewodnik do petrografii. Wydawnictwo AGH, Kraków 2008.

[4] Miller F.A., Wilkins C.H.: Infrared spectra and characteristic frequencies of inorganic ions. Anal. Chem. 1952, vol. 24, no. 8, s. $1253-1294$.

[5] Mineralogy Database, strona internetowa, www.webmineral.com (dostęp: listopad 2016).

[6] Müller Ch.M., Pejcic B., Esteban L., Delle Piane C., Raven M., Mizaikoff B.: Infrared Attenuated Total Reflectance Spectroscopy: An Innovative Strategy for Analyzing Mineral Components in Energy Relevant Systems. Scientific Reports 2014, no. 4, 6764.2.

[7] Palayangoda S.S., Nguyen Q.P.: An ATR-FTIR procedure for quantitative analysis of mineral constituents and kerogen in oil shale. Oil Shale 2012, vol. 29, no. 4, s. 344-356.

[8] Povarennykh A.S.: The use of infrared spectra for the determination of minerals. American Mineralogist 1978, vol. 63, no. $9-10$, s. $956-959$.

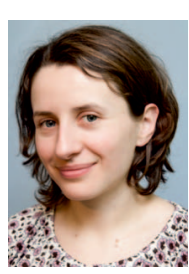

Mgr Urszula ZAGÓRSKA

Specjalista inżynieryjno-techniczny w Zakładzie Geofizyki Wiertniczej.

Instytut Nafty i Gazu - Państwowy Instytut Badawczy ul. Lubicz 25 A

31-503 Kraków

E-mail: urszula.jonkis@inig.pl
[9] Rietveld H.M.: A profile refinement method for nuclear and magnetic. Journal of Applied Crystalography 1969, vol. 2, s. $65-71$.

[10] Skupio R.: Wykorzystanie przenośnego spektrometru XRF do pomiarów składu chemicznego skał. Nafta-Gaz 2014, nr 11, s. 771-777.

[11] Stuart B.: Infrared Spectroscopy: Fundamentals and Applications. ACOL Series, Wiley, Chichester, UK 2004.

[12] Środoń J., Drits V.A., McCarty D.K., Hsieh J.C.C., Eberl D.D.: Quantitative analysis of clay-bearing rocks from random preparations. Clays and Clay Minerals 2001, vol. 49, no. 6, s. $514-528$.

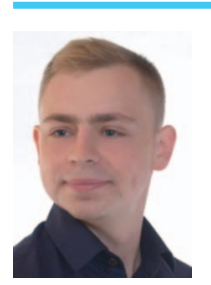

Mgr Mateusz ORZECHOWSKI

Specjalista inżynieryjno-techniczny w Zakładzie Geofizyki Wiertniczej.

Instytut Nafty i Gazu - Państwowy Instytut Badawczy ul. Lubicz 25 A

31-503 Kraków

E-mail: mateusz.orzechowski@inig.pl

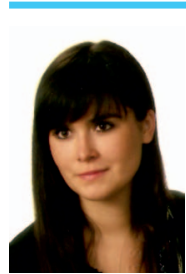

Mgr Katarzyna HRYNIEWICKA

Specjalista ds. spektroskopii molekularnej

MS Spektrum

ul. Bociana 22

30-001 Kraków

E-mail:kh@msspektrum.pl 